\title{
1 Non-production vegetation has a positive effect on ecological processes in
}

2 agroecosystems

4 Bradley S. Case ${ }^{1 *}$, Jennifer L. Pannell ${ }^{1}$, Margaret C. Stanley ${ }^{2}$, David A. Norton ${ }^{3}$, Anoek

5 Brugman ${ }^{1,4}$, Matt Funaki ${ }^{1}$, Chloé Mathieu ${ }^{1}$, Cao Songling ${ }^{1,5}$, Febyana Suryaningrum ${ }^{1}$,

6 Hannah L. Buckley ${ }^{1}$

$8{ }^{1}$ School of Science, Auckland University of Technology, Auckland, New Zealand

$9{ }^{2}$ School of Biological Sciences, University of Auckland, Auckland, New Zealand

$10{ }^{3}$ Te Kura Ngahere/School of Forestry, University of Canterbury, Christchurch, New Zealand

$11{ }^{4}$ HAS University of Applied Sciences, 's-Hertogenbosch, The Netherlands

$12{ }^{5}$ Sichuan Agricultural University, College of Agronomy, Chengdu, China

* Author for correspondence: Bradley.Case@aut.ac.nz

Abstract

An ever-expanding human population, ongoing global climatic changes, and the spread of intensive farming practices is putting increasing pressure on agroecosystems and the inherent biodiversity they contain. Non-production vegetation elements, such as woody patches, riparian margins, and inter-crop and restoration plantings, are vital for conserving biodiversity in agroecosystems and are therefore considered key to sustaining the biotic and abiotic processes underpinning sustainable and resilient agroecosystems. Despite this critical role, there is a surprising lack of synthesis of which types of non-production vegetation elements drive and/or support ecological processes and the mechanisms by which this occurs. Using a systematic, quantitative literature review of 342 articles, we asked: what are the effects of non-production vegetation elements on agroecosystem processes and how are these processes measured within global agroecosystems? Our literature search focussed on the effects of non-production vegetation related to faunal, weed, disease, and abiotic processes. The majority (61\%) of studies showed positive effects on ecological processes: non-

30 production vegetation increased the presence, level or rate of the studied process. However, rather than directly measuring ecosystem processes, $83 \%$ of studies inferred processes using proxies for ecosystem function, such as biodiversity and soil physicochemical properties.

33 Studies that directly measured non-production vegetation effects focussed on a limited

34 number of vegetation effects including comparisons of vegetation types, farm-scale 
35 configuration, and proximity to vegetation. Moreover, studies directly measuring ecosystem 36 processes were similarly limited, dominated by invertebrate biocontrol, predator and natural

37 enemy spillover, animal movement, and ecosystem cycling. We identify research gaps and

38 present a pathway for future research in understanding the ecosystem components and

39 processes that build resilient, sustainable agroecosystems.

40

41 Keywords: Agriculture, biodiversity, non-production vegetation, connectivity, ecosystem

42 disservice, ecosystem function, ecosystem process, ecosystem service, landscape, multi-

43 functionality, resilience, sustainable agroecosystems

44

45

46 


\section{Introduction}

Agroecosystems, comprising over $40 \%$ of the Earth's terrestrial surface, are under increasing pressure as the demand for secure sources of food and other resources increases, the increased uptake of intensive agricultural practices, and as climatic processes, disturbance regimes, and habitats continue to be disrupted or degraded (e.g., Godfray et al. 2010, Tilman et al. 2011, Smith et al. 2016). Such pressures are drastically altering agroecosystems and their abilities to provide and sustain services at the accelerating rate of human demand (Rockström et al. 2017). A consequence of this reality is dramatic losses of biodiversity across agricultural landscapes globally (Newbold et al. 2015). There have been discussions whether the biodiversity crisis could be best mitigated via larger conservation set-asides ('land sparing'), or whether the focus should be on maintaining, retaining, and restoring components of the original diversity of taxa, habitats and ecosystem attributes within the production matrix itself ('land sharing') (e.g., Green et al. 2005). The outcome of these discussions is that perhaps both approaches are essential (Kremen 2015), and that even small biodiversity elements within intensive agricultural landscapes are critical for creating agroecosystems that exhibit 'multi-functionality' (Barral et al. 2015; see Box 1 - glossary). There is increasing evidence (e.g. Tilman and Downing 1994, Srivastava and Vellend 2005, Cardinale et al. 2006, van der Plas 2019), that a positive relationship exists between biodiversity and ecosystem function, although the exact nature and strength of the relationship is process- and context-dependent (Gamfeldt and Roger 2017, van der Plas 2019). Thus, biodiversity itself is fundamental to sustaining the biotic and abiotic ecosystem processes that underpin sustainable and resilient agroecosystems ('functional biodiversity', sensu Moonen and Barberi 2008, Martin et al. 2019) and the downstream delivery of ecosystem services. There are two contributions of functional biodiversity that must be considered. First, key taxa can have disproportionate effects within agroecosystems, and their loss from a local species pool can have detrimental impacts on biodiversity and ecological processes (Chapin et al. 1997); the decline in bee populations in some regions provides a poignant example of this, having deleterious consequences for pollination and, ultimately, crop productivity (Vanbergen and the Insect Pollinators Initiative 2013). This highlights that, while species richness is important, more critical is the functional roles that particular species play in agroecosystems, such as in multi-trophic processes (Soliveres et al. 2016) and in the decomposition of litter and detritus (Gessner et al. 2010).

Second, non-production vegetation elements provide the surrounding context in which the production components of agroecosystems are embedded. These non-production 
81 vegetation elements vary in their size, composition and spatial arrangement in agricultural

82 landscapes; these aspects thus determine the types of processes that can be supported in

83 agroecosystems. A number of government programmes across the globe, such as agri-

84 environment schemes in the UK, USA, and Europe, have focused on creating/maintaining

85 non-production vegetation components in agricultural landscapes, with variable outcomes

86 (e.g., Batáry et al. 2015, Wood et al. 2015, Żmihorski et al. 2016, Jones et al. 2017). Multiple

87 processes are required to achieve a resilient ecosystem (Oliver et al. 2015), but we lack

88 synthesis in our understanding of the role of non-production vegetation elements in multiple

89 ecosystem processes. If biodiversity positively affects ecosystem function, we need to

90 understand which and how non-production vegetation elements support ecosystem processes.

91 In this review we evaluate the role of non-production vegetation elements within

92 agricultural landscapes, in terms of supporting both abiotic and biotic processes at different

93 spatio-temporal scales, and thus their importance in achieving sustainable, resilient

94 agroecosystems. Such non-production vegetation includes linear features like hedgerows,

95 shelterbelts, corridors, and riparian buffers, as well as patches of vegetation composed of

96 restoration plantings and remnant patches, and other inter-crop components such as

97 underplantings, buffer strips, and cover crops. In particular, we ask: What functions and

98 processes are associated with non-production vegetation components and how are these

99 processes measured within global agroecosystems? We used a quantitative review

100 methodology (Pickering \& Byrne, 2014) to search the relevant literature to obtain a sample of

101 research articles using keywords. We scored papers based on how non-production elements

102 were measured, and the contributions to biodiversity and ecosystem function(s) demonstrated

103 by these non-production elements. We use these results to make recommendations for future

104 research that will support the maintenance and enhancement of the world's sustainable and

105 resilient agroecosystems.

\section{Quantitative literature review}

108 We searched the international literature for relevant articles following a modified systematic

109 review protocol (Pickering \& Byrne 2014). Relevant articles were defined as those that

110 described primary research conducted on farmland that addressed questions regarding any

111 ecological function(s) associated with non-crop vegetation. Five distinct search strings,

112 comprised of various keywords (Table S1) were designed to find relevant papers addressing

113 the following broad topics related to non-production vegetation in agroecosystems; faunal

114 diversity and use of vegetation; spatial arrangement of vegetation in the landscape; pests and 
115 disease in vegetation; weeds in vegetation; abiotic functional responses to vegetation. The hit

116 rate of 30 scholarly databases was tested using all five search strings, and nine were selected

117 based on the proportion of relevant hits: BASE, BioOne, Google Scholar, JSTOR, Jurn,

118 ProQuest, Science Direct, Scopus, and Web of Science. Each search string was entered into

119 each database in turn, and all relevant articles were downloaded (where relevance was

120 determined by reading the abstract). If no relevant articles were found for 100 hits, we moved

121 on to the next search. For every relevant article found, we also checked all citing articles

122 using the "Cited by" function in Google Scholar. After the initial two databases were

123 searched, we extracted all keywords from papers and ranked them by the number of

124 occurrences. We updated the search strings to include any commonly-used keywords that

125 were missing from the strings (Supplementary Materials Table S1). Finally, once all searches

126 were complete, we extracted and cross-referenced all reference lists from the downloaded

127 articles using ParsCit (Kan et al. 2011), and checked all papers that were cited three or more

128 times and were not already in our collection.

129 A total of 704 articles were read and 342 were included using the criteria that they

130 were: (1) empirical (not modelling or meta-analysis) studies within agroecosystems; and (2)

131 they at least discussed the effects of non-production vegetation on processes, not just

132 biodiversity, within agroecosystems. A range of initial variables, were extracted from every

133 included article, describing the study design, the stated aims/questions of the study, the taxa

134 studied (e.g., birds, invertebrates, mammals), the non-crop vegetation type (e.g., woody,

135 herbaceous) and configuration (e.g., forest fragments, hedgerows, corridors) (Table S2), the

136 spatial grain and extent of the study (e.g., field margin, field, farm, catchment, region). We

137 noted whether the inferences made in the paper were regarding ecological processes,

138 biodiversity or both, and what processes were studied, such as biocontrol, pollination,

139 nutrient cycling (Table S3). Finally, we recorded the methods that were used to measure

140 processes directly, including direct observations of animal movements or feeding events,

141 herbivory rate observations, respiration or decomposition rates, or whether the process was

142 inferred via indirect observations or measurements, such as using relative differences in

143 predator relative abundance to infer predation rates between habitat types or using soil

144 physicochemical variables to infer nutrient cycling.

145 The 342 relevant research articles had a large global distribution (Fig. S1), and

146 resulted in 229 described independent studies about fauna, 61 studies about soil and water

147 processes, 32 studies about weeds, and 17 about diseases (human diseases, $\mathrm{n}=5$; other

148 animal diseases, $\mathrm{n}=2$; plant diseases, $\mathrm{n}=10$ ); note that a few articles included more than one 
149 independent study. A total of 500 different research questions were asked within the articles

150 regarding the effects of non-production vegetation on agroecosystem processes. Globally,

152 Non-production vegetation positively affects agroecosystem function

153 Our synthesis shows that the study aims, as stated by reviewed articles, address a wide

154 variety of agroecosystem processes (Fig. 1). Across the 342 reviewed articles and 500

155 independent research questions posed within these articles, the majority of effects of non-

156 production vegetation on ecological processes were positive in that non-crop vegetation

157 increased the presence, level or rate of the studied process $(58 \% ; n=290)$. Of these

158 processes, $10 \%(\mathrm{n}=51)$ would be classified as 'ecosystem disservices' because they

159 contribute negatively to human-preferred outcomes in agroecosystems. Of the remaining $90 \%$

$160(\mathrm{n}=449)$ of processes tested, non-crop vegetation caused increases in $61 \%$ of the processes

161 (faunal biodiversity, $n=146$; faunal processes, $n=64$; soil and water processes, $n=53$; weed

162 processes, $n=4$; disease processes, $n=5$ ), caused decreases in $4 \%$ of the processes, caused

163 variable responses (where the outcome depended on another factor such as vegetation type,

164 taxon/taxa involved, landscape configuration or season) in 14\% of the processes and was

165 non-significant or unclear in $21 \%$ of processes. Of the 'ecosystem disservice' processes, non-

166 crop vegetation improved (i.e., reduced the disservice) $35 \%$ of all studied processes (faunal

167 processes, $\mathrm{n}=11$; weed processes, $\mathrm{n}=5$; diseases processes, $\mathrm{n}=2$ ).

168 The most-commonly studied types of non-production vegetation elements were

169 classed as 'patches', meaning any non-linear fragment that was either planted, or more

170 frequently remnant in the agricultural landscape $(n=183$; Fig. 2). Studies that tested at least

171 two different types of non-production vegetation elements ('mixed'; $n=109$ ) and hedgerows

172 or field margin plantings ('borders'; $\mathrm{n}=98$ ) were also studied more frequently than any of

173 the other types, surprisingly including corridors $(n=5$; Fig. 2), which have been touted as

174 important connecting elements in agriculture landscape (Correa Ayram et al. 2016). Whether

175 or not non-production vegetation was present in the landscape ('provision'; $n=103$ ) and the

176 comparison of different non-production vegetation types $(n=95)$ were the most commonly

177 tested effects of non-production vegetation on agroecosystem processes. Hedgerows/borders

178 and shelterbelts showed relatively more increasing (rather than variable, decreasing or non-

179 significant) effects than other vegetation types, across a range of tested effects (Fig. 2). 


\section{Agroecosystem processes are mostly inferred, not directly measured}

182 The ability to draw strong conclusions regarding the effects of non-production vegetation on 183 agroecosystem processes is dependent on the degree to which processes are measured

184 directly compared to whether indicator or proxy variables are used to represent those

185 processes. In our review, very few studies directly measured the effects of non-production

186 vegetation on agroecosystem processes. The majority of the 500 research questions from the

187342 reviewed articles $(83 \% ; \mathrm{n}=416)$ were posed using variables that have only been

188 hypothesised to represent ecosystem function, such as biodiversity and soil physicochemical

189 properties. There is only variable and/ or weak evidence for many hypothesised causal

190 relationships between such proxy variables and ecosystem functions, such as the links

191 between biodiversity and soil carbon, decomposition rates, or herbivory (van der Plas 2019)

192 or the links between indicators of soil properties and processes such as nutrient cycling and

193 water quality (Bünemann et al. 2018). In other cases, links have been shown to be weak or

194 absent. For example, land use types are often used as a proxy for ecosystem function, but this

195 has been shown to be unreliable (Bünemann et al. 2018) and there have been suggestions that

196 more work needs to be done to model soil processes before causal relationships can be

197 determined between processes and easy-to-measure indicator or proxy variables (Vereecken

198 et al. 2016). Thus, our results show that greater research emphasis needs to be put on directly

199 measuring ecosystem functions in agroecosystems associated with non-production vegetation

200 and disentangling their relationships with other variables such as biodiversity and abiotic

201 properties.

202 The research questions that used direct measurements of ecosystem processes rather

203 than inferred links ( $n=84$ out of 500) examined a limited range of taxa and ecosystem

204 processes and used a limited set of methods to measure those processes (Table 1), revealing

205 significant research gaps in this field. For example, $43 \%$ of studies on ecosystem processes

206 related to fauna in non-production vegetation elements, looked at invertebrate biocontrol and

207 natural enemies of crop pests, such as parasites ( $n=26$ out of 61 studies); indeed, the

208 majority of these were invertebrate-related studies $(n=38)$, while the remainder studied birds

$209(\mathrm{n}=11)$, mammals $(\mathrm{n}=8)$, multiple taxa $(\mathrm{n}=3)$, and reptiles $(\mathrm{n}=1)$. For soil and water-

210 related ecosystem processes, 19 out of 20 studies looked at ecosystem cycling processes such

211 as decomposition, carbon cycling and nutrient cycling; no studies directly measured soil

212 erosion, a key process in agroecosystems often touted to be positively affected by non-

213 production vegetation. Only three weed studies directly measured processes by monitoring

214 weed invasion over time; all other studies, including 30 on weeds and 17 on diseases inferred 
215 processes sampling the presence and/or abundance of weed- and disease-related taxa in

216 different non-production vegetation elements and the production matrix.

217 Of the research question that addressed directly-measured processes, the majority

$218(79 \% ; \mathrm{n}=66)$ showed increases in the presence, level or rate of the ecosystem process,

219 compared to few that showed variable $(n=8)$, decreasing $(n=3)$ or non-significant $(n=7)$

220 effects (Fig. 3). This suggests that, despite the relatively minimal use of direct process

221 measurements, there is quantitative support for the idea that non-production vegetation

222 beneficially affects agroecosystem processes. Across all tested vegetation effects, ecosystem

223 cycling $(\mathrm{n}=19)$, biocontrol $(\mathrm{n}=15)$, spillover $(\mathrm{n}=11)$, and animal movement $(\mathrm{n}=10)$ and

224 were the processes most frequently measured directly, with almost all of these (82\%)

225 showing positive (increasing) outcomes. Certainly, the last two decades has seen a

226 proliferation of studies on the role of non-production vegetation in supporting beneficial

227 invertebrates in agroecosystems, in terms of providing habitat and resources (e.g., Knapp and

228 Řezáč 2015, Saunders et al. 2016), facilitating their movement into adjacent farmland (e.g.,

229 Inclán et al. 2015), and for generally enhancing biocontrol of invertebrates that impact on

230 crop production (e.g., Pywell et al. 2015). There were clear positive effects of several

231 different types of non-production vegetation elements, in comparison to production areas, on

232 ecosystem cycling, such as decomposition, soil respiration, and nitrogen mineralisation (Fig.

233 3). Conversely, our review also revealed gaps in the types of processes investigated. For

234 example, few studies directly measured processes related to pest competition and movement,

235 the dispersal and invasion of weeds into the production matrix, and other abiotic processes,

236 such as soil erosion and sedimentation (Fig. 3). Further, our results suggest that processes

237 related to non-production vegetation were not commonly directly-tested at landscape scales

238 (e.g., landscape complexity effect, Fig. 3), with many effects tending to be inferred indirectly

239 via indices of land use intensity and composition (e.g., Jonsson et al. 2012).

Available methods should be harnessed to improve the direct measurement of processes

242 Eleven methods were employed across the 84 research questions emerging from studies

243 directly measuring non-production vegetation effects on ecosystem processes (Table 1). Of

244 these 11 methods, only six methods were used in more than one study, and mainly comprised

245 direct observations and food consumption amounts or rates for faunal studies and litter bag

246 experiments and soil flux measurements. This suggests that both the biotic and abiotic

247 methods typically employed are limited to those that are easier to conduct in the field; for

248 instance, vegetation effects on invertebrate predation is likely easier to document than those 
249 on competition, and disease transmission and soil gas flux measurements are relatively 250 straightforward compared to those of erosion rates or nutrient and water flow dynamics.

251 There is a range of underused methods available for measuring ecosystem processes

252 that could be usefully applied in agroecosystem research. For instance, landscape genetics

253 methods, which are used extensively in natural habitats (Manel et al. 2013), could be

254 employed more widely in agroecosystem studies to reconstruct the movement, current gene

255 flow and past history of native fauna in the fragmented habitats of agroecosystems (e.g., Jaffé

256 et al. 2016). Temporal studies that track the movement of native and pest animals, weeds, and

257 diseases through agroecosystems would allow us to assess the role of non-production

258 vegetation elements in providing both connectivity for native species (affecting ecosystem

259 resilience) and pathways for the spread of unwanted organisms. For example, non-invasive

260 and low-cost methods for direct tracking of animals are available such as the use of rubidium

261 as an isotope tracer to track invertebrate movement (Payne and Dunley 2002), or GPS to

262 quantify the movement of mobile macrofauna (e.g. Neilly and Schwarzkopf 2017). Temporal

263 studies involving experimental tracers could also be used to assess how non-production

264 vegetation elements affect ecosystem processes such as sedimentation and run-off (e.g.,

265 Mabit et al. 2018), and the potential level of below-ground connectivity between different

266 ecosystem components. Indeed, the roles of non-production vegetation elements for farm-to-

267 catchment scale water flow and movement was particularly understudied in the literature we 268 reviewed.

269 Experimental studies similarly provide strong inference for tests of process under

270 manipulation; even large-scale manipulative experiments can be logistically easier to conduct

271 in agroecosystems than in native ecosystems (e.g., Resasco et al. 2017). Experimental

272 approaches in agroecosystems could also include subsequent measurements of social and

273 economic outcomes, such as crop yield, meat yield as outputs, social outputs (e.g., Maseyk et

274 al. 2017), thus expanding the scope of the experiment to test for effects of non-production

275 vegetation elements on multi-functionality. Greater natural history and species-level

276 understanding is needed to build knowledge of the processes that support resilient ecosystems

277 (Oliver et al. 2015), and enable the scaling up of key processes using appropriate modelling

278 to predict landscape-level ecosystem outcomes (Padulles Cubino et al. 2018).

280 The role of non-production vegetation is embedded within the socio-ecological context

281 This review has shown that non-production vegetation can support the processes that

282 underpin functional biodiversity in resilient, sustainable agroecosystems. However, 
283 fundamentally, agroecosystems are a human creation and so our choices and subsequent

284 behaviours, such as maintaining or restoring non-production vegetation patches in

285 agricultural landscapes, ultimately determine the structure and functioning of these

286 landscapes (Fig. 4A; Landis 2017). Our review shows that there are gaps in our

287 understanding of the broad range of agroecosystem processes that are likely to be affected by

288 non-production vegetation elements. If we aim to achieve sustainable and resilient

289 agroecosystems, research efforts to expand biological knowledge must be embedded in the

290 'cultural context' of agroecosystems, or we risk missing the role of people and the influence

291 of their decisions in maintaining or disrupting the key biological processes and relationships

292 (Fig. 4B).

293 People make land management decisions, including those involving non-production

294 vegetation, for a wide variety of reasons including economic consideration, personal values,

295 and their knowledge of biodiversity and its role in the farming landscape (Norton and Reid

296 2013). For example, a primary driver of land management decisions is the economics of the

297 farm business, but this is not always in conflict with good functional biodiversity

298 management (Smith and Watson, 2018) and further, can be incentivised by local and national

299 government policy (Hanley et al. 2012). How we value biodiversity intrinsically, such as for

300 the enjoyment of native bird song, the provision of pollination or harvestable material, or for

301 soil nutrient mitigation, has been shown to provide both incentive for good biodiversity

302 management and economic benefits (Cáceres et al. 2015). Traditional ecological knowledge

303 and the cultural importance of particular species or habitats can positively influence the

304 maintenance and enhancement of non-production vegetation and associated biodiversity (e.g.,

305 Ruiz-Mallén and Corbera, 2013); considerably more work is required to fully understand the

306 contribution of these decisions to enhancing agroecosystem processes besides maintaining

307 diversity and preventing extinctions. In contrast, fear of native species such as large

308 mammalian predators, or other forms of human wildlife conflict can impact on the

309 management and use of non-production vegetation in farming landscapes (Sitati et al. 2005).

310 Pest or disease vector taxa provide an economic incentive for management and control;

311 where such species also negatively affect native biodiversity, this provides a win-win for

312 farming and good biodiversity management. For instance, the control of the invasive

313 brushtail possum (Trichosurus vulpecula) in New Zealand, which is both a vector for bovine

314 tuberculosis infection in cattle and a rapacious predator on native birds, has led to significant

315 economic and ecological gains (Byrom et al. 2016). Conversely, economic returns reaped via

316 the management of non-production vegetation for one ecosystem function (e.g., pollination) 
317 can at times occur at the expense of other processes (e.g., biocontrol) (Shackelford et al.

318 2013). Thus, management decisions in agroecosystems arise from such complexities related

319 to the socio-ecological context and often result in trade-offs between competing viewpoints

320 (Saunders et al. 2016), potentially disrupting one or many parts of the system (e.g., Fig. 4B).

321 In light of this cultural and ecological context (i.e., land management decisions are at

322 the farm level, processes occur at multiple scales, and management actions need social

323 license), ecological understanding needs to be built within a framework that encompasses

324 these three main components: the configuration of non-production vegetation elements in the

325 landscape, the role of important taxa/functional groups and how these taxa are supported by

326 non-production vegetation, and the interplay of these components with management

327 decisions (Saunders et al. 2016). However, research should not be limited to a narrow set of

328 topics to inform landscape design, but on as many processes as possible (Landis 2017). We

329 advocate for transdisciplinary research on the role of non-production vegetation that capture a

330 broad range of cultural and ecological processes across multiple scales; such research is

331 necessary for informing decision making that will achieve sustainable and resilient systems

332 that support higher functional biodiversity.

333 Further, because agroecosystem decision making operates at the farm level, while

334 functional biodiversity often operates at coarser scales (Kleijn et al. 2019), multi-level

335 thinking is required to manage functional biodiversity across spatial scales (Box 2). The

336 spatial scale at which ecosystem measurements should be taken needs to consider: (1) the

337 scale of the organisms or the processes under study, (2) the size and arrangement of the non-

338 production vegetation elements to be evaluated, and (3) the logistical or other constraints of

339 the methods used to measure the process. Where possible, pilot studies or prior information

340 from the literature (e.g., Welsch et al. 2019) should be used to justify the spatial scale of

341 sampling. Further, fragmented landscapes cannot sustain all species because some, for

342 instance, require large home ranges; however, where multi-functionality is the goal, rather

343 than solely conservation of individual species, resilient systems need not contain maximal

344 landscape biodiversity to be able to adapt to recover after perturbations such as drought or

345 fire, or adapt to shifting conditions such as increasing temperatures or rising nutrient inputs

346 (Lindenmayer et al. 2008). Instead, the focus should be on restoring, enhancing and

347 manipulating non-production vegetation elements to create connected, structurally complex

348 agricultural landscapes with a diversity of species across key functional groups at multiple

349 scales (Fisher et al. 2006). 


\section{Conclusions}

352 Non-crop vegetation elements in agroecosystems make a significant, positive contribution to

353 biodiversity and ecosystem functioning. Nonetheless, there are gaps in our understanding that

354 can be filled by studies focussing on disentangling the role of different taxa, (or functional

355 groups) across non-production vegetation elements, incorporating a wider variety of

356 processes and spatial scales, and employing novel and underused methods. Indeed, if we are

357 to increase and enhance functional biodiversity, future efforts should be focussed on

358 measuring and monitoring relevant biotic and abiotic ecosystem processes at landscape scales

359 within the context of farm management scenarios. This will lead to new insights into how the

360 types, amounts, and arrangements of non-production vegetation elements, mediated by

361 decision making at the community level, can result in resilient agroecosystems into the

362 future.

\section{Acknowledgements}

365 This work was supported by funding from the New Zealand Ministry of Business, Innovation 366 and Employment (New Zealand's Biological Heritage NSC, C09X1501). We thank Mia

367 Jüllig for help with figure creation (http://www.paperdog.co.nz/about/).

\section{References cited}

Altieri, M.A., 1999. The ecological role of biodiversity in agroecosystems. Agriculture, Ecosystems and Environment, 74, 19-31.

Barral, M.P., Benayas, J.M.R., Meli, P. and Maceira, N.O., (2015). Quantifying the impacts of ecological restoration on biodiversity and ecosystem services in agroecosystems: a global meta-analysis. Agriculture, Ecosystems \& Environment, 202, 23-231.

Batáry, P., Dicks, L.V., Kleijn, D. and Sutherland, W.J., 2015. The role of agri $\square$ environment schemes in conservation and environmental management. Conservation Biology, 29, 1006-1016.

Beller, E.E., Spotswood, E.N., Robinson, A.H., Anderson, M.G., Higgs, E.S., Hobbs, R.J., Suding, K.N., Zavaleta, E.S., Grenier, J.L. and Grossinger, R.M., 2018. Building 
384 Byrom, A.E., Innes, J. and Binny, R.N., 2016. A review of biodiversity outcomes from possum-focused pest control in New Zealand. Wildlife Research, 43, 228-253.

Cardinale, B.J., Srivastava, D.S., Duffy, J.E., Wright, J.P., Downing, A.L., Sankaran, M. and Jouseau, C., 2006. Effects of biodiversity on the functioning of trophic groups and ecosystems. Nature, 443, 989.

Cáceres, D.M., Tapella, E., Quétier, F. and Díaz, S., 2015. The social value of biodiversity and ecosystem services from the perspectives of different social actors. Ecology and Society, 20.

Chapin, F.S., Walker, B.H., Hobbs, R.J., Hooper, D.U., Lawton, J.H., Sala, O.E. and Tilman, D., 1997. Biotic control over the functioning of ecosystems. Science, 277, 500-504.

\section{Correa Ayram, C.A., Mendoza, M.E., Etter, A. and Salicrup, D.R.P., 2016. Habitat} connectivity in biodiversity conservation: a review of recent studies and applications. Progress in Physical Geography, 40, 7-37.

Fischer, J., Lindenmayer, D.B. and Manning, A.D., 2006. Biodiversity, ecosystem function, and resilience: ten guiding principles for commodity production landscapes. Frontiers in Ecology and the Environment, 4, 80-86.

Gamfeldt, L., Hillebrand, H. and Jonsson, P.R., 2008. Multiple functions increase the importance of biodiversity for overall ecosystem functioning. Ecology, 89, 1223-1231.

Gessner, M.O., Swan, C.M., Dang, C.K., McKie, B.G., Bardgett, R.D., Wall, D.H. and Hättenschwiler, S., 2010. Diversity meets decomposition. Trends in Ecology \& Evolution, 25, 372-380.

Green, R.E., Cornell, S.J., Scharlemann, J.P.W. \& Balmford, A. (2005). Farming and the fate of wild nature. Science, 307, 550-555.

Hanley, N., Banerjee, S., Lennox, G.D. and Armsworth, P.R., 2012. How should we incentivize private landowners to 'produce'more biodiversity? Oxford Review of Economic Policy, 28, 93-113.

Inclán, D.J., Cerretti, P. and Marini, L., 2015. Landscape composition affects parasitoid spillover. Agriculture, Ecosystems \& Environment, 208, 48-54.

Jaffé, R., Castilla, A., Pope, N., Imperatriz-Fonseca, V.L., Metzger, J.P., Arias, M.C. and Jha, S., 2016. Landscape genetics of a tropical rescue pollinator. Conservation Genetics, 17, 267-278. Hawczak, A., Hughes, G.O., Pretty, J.L., Scarlett, P.M. and Gooday, R.D., 2017. Do agri $\square$ environment schemes result in improved water quality? Journal of Applied 
Ecology, 54, 537-546.

Kan M-Y, Councill IG, Giles CL, Luong M-T, Hoang Do HN (2011) ParsCit version 130908.

Kleijn, D., Bommarco, R., Fijen, T.P., Garibaldi, L.A., Potts, S.G. and van der Putten, W.H., 2018. Ecological intensification: bridging the gap between science and practice. Trends in Ecology \& Evolution, 34, 154-166.

Knapp, M. and Řezáč, M., 2015. Even the smallest non-crop habitat islands could be beneficial: distribution of carabid beetles and spiders in agricultural landscape. PLoS one, 10, e0123052.

Kremen, C., 2015. Reframing the land $\square$ sparing/land $\square$ sharing debate for biodiversity

Landis, D.A., 2017. Designing agricultural landscapes for biodiversity-based ecosystem services. Basic and Applied Ecology, 18, 1-12.

Lawton, J.H., Brotherton, P.N.M., Brown, V.K., Elphick, C., Fitter, A.H., Forshaw, J., Haddow, R.W., Hilborne, S., Leafe, R.N., Mace, G.M. and Southgate, M.P., 2010. Making Space for Nature: a review of England's wildlife sites and ecological network. Report to DEFRA, 107.

Lindenmayer, D., Hobbs, R.J., Montague $\square$ Drake, R., Alexandra, J., Bennett, A., Burgman, M., Cale, P., Calhoun, A., Cramer, V., Cullen, P. and Driscoll, D., 2008. A checklist for ecological management of landscapes for conservation. Ecology Letters, 11, 78-91.

Mabit, L., Gibbs, M., Mbaye, M., Meusburger, K., Toloza, A., Resch, C., Klik, A., Swales, A. and Alewell, C., 2018. Novel application of Compound Specific Stable Isotope (CSSI) techniques to investigate on-site sediment origins across arable fields.

\section{Geoderma, 316, 19-26.}

Manel, S. and Holderegger, R., 2013. Ten years of landscape genetics. Trends in Ecology \& Evolution, 28, 614-621.

Manning, P., Plas, F., Soliveres, S., Allan, E., Maestre, F.T., Mace, G., Whittingham, M.J. and Fischer, M., 2018. Redefining ecosystem multifunctionality. Nature ecology \& evolution, 2, 427-436.

Maseyk, F.J., Dominati, E.J., White, T. and Mackay, A.D., 2017. Farmer perspectives of the on-farm and off-farm pros and cons of planted multifunctional riparian margins. Land Use Policy, 61, 160-170.

Moonen, A.C. and Barberi, P., 2008. Functional biodiversity: an agroecosystem approach. Agriculture, Ecosystems \& Environment, 127, 7-21. 
452 Neilly, H. and Schwarzkopf, L., 2017. The response of an arboreal mammal to livestock

453 grazing is habitat dependant. Scientific Reports, 7, 17382.

454 Norton, D. and Reid, N, 2013. Nature and farming: Sustaining native biodiversity in

$455 \quad$ agricultural landscapes. Csiro Publishing.

456 Oliver, T.H., Heard, M.S., Isaac, N.J., Roy, D.B., Procter, D., Eigenbrod, F., Freckleton, R.,

457 Hector, A., Orme, C.D.L., Petchey, O.L. and Proença, V., 2015. Biodiversity and

458 resilience of ecosystem functions. Trends in Ecology \& Evolution, 30, 673-684.

459 Oliver, T.H., Isaac, N.J., August, T.A., Woodcock, B.A., Roy, D.B. and Bullock, J.M., 2015.

460 Declining resilience of ecosystem functions under biodiversity loss. Nature

$461 \quad$ Communications, 6, p.10122.

462 Padullés Cubino, J., Buckley, H.L., Day, N.J., Pieper, R. and Curran, T.J., 2018.

463 Community $\square$ level flammability declines over 25 years of plant invasion in grasslands.

$464 \quad$ Journal of Ecology, 106, 1582-1594.

465 Payne, J.C. and Dunley, J.E., 2002. Use of an elemental marker, rubidium, to study dispersal

466 of aquatic insects. Journal of the North American Benthological Society, 21, 715-727.

467 Pickering, C. and Byrne, J. (2014). The benefits of publishing systematic quantitative

468 literature reviews for $\mathrm{PhD}$ candidates and other early-career researchers. Higher

469 Education Research \& Development, 33(3), 534-548.

470 Pywell, R.F., Heard, M.S., Woodcock, B.A., Hinsley, S., Ridding, L., Nowakowski, M. and

471 Bullock, J.M., 2015. Wildlife-friendly farming increases crop yield: evidence for

472 ecological intensification. Proceedings of the Royal Society B: Biological Sciences, 282,

47320151740.

474 Resasco, J., Bruna, E.M., Haddad, N.M., Banks $\square$ Leite, C. and Margules, C.R., 2017. The

475 contribution of theory and experiments to conservation in fragmented landscapes.

476 Ecography, 40, 109-118.

477 Rockström, J., Williams, J., Daily, G., Noble, A., Matthews, N., Gordon, L., Wetterstrand,

478 H., DeClerck, F., Shah, M., Steduto, P. and de Fraiture, C., 2017. Sustainable

479 intensification of agriculture for human prosperity and global sustainability. Ambio, 46,

$480 \quad 4-17$.

481 Ruiz-Mallén, I. and Corbera, E., 2013. Community-based conservation and traditional

482 ecological knowledge: implications for social-ecological resilience. Ecology and

483 Society, 18.

484 Saunders, M.E., Peisley, R.K., Rader, R. and Luck, G.W., 2016. Pollinators, pests, and

485 predators: Recognizing ecological trade-offs in agroecosystems. Ambio, 45, 4-14. 
Sitati, N.W., Walpole, M.J. and Leader-Williams, N., 2005. Factors affecting susceptibility of farms to crop raiding by African elephants: using a predictive model to mitigate conflict. Journal of Applied Ecology, 42, 1175-1182.

Smith, P., House, J.I., Bustamante, M., Sobocká, J., Harper, R., Pan, G., West, P.C., Clark, J.M., Adhya, T., Rumpel, C. and Paustian, K., 2016. Global change pressures on soils from land use and management. Global Change Biology, 22, 1008-1028.

Smith, R. and Watson, A., 2018. Working with nature to improve the environment and profitability of irrigated cotton production at 'Kilmarnock', Namoi Valley, New South Wales. Ecological Management \& Restoration, 19, 63-72.

Shackelford, G., Steward, P.R., Benton, T.G., Kunin, W.E., Potts, S.G., Biesmeijer, J.C. and Sait, S.M., 2013. Comparison of pollinators and natural enemies: a meta $\square$ analysis of landscape and local effects on abundance and richness in crops. Biological Reviews, 88, 1002-1021.

Srivastava, D.S. and Vellend, M., 2005. Biodiversity-ecosystem function research: is it relevant to conservation? Annu. Rev. Ecol. Evol. Syst., 36, 267-294.

Tilman, D. and Downing, J.A., 1994. Biodiversity and stability in grasslands. Nature, 367, 363.

Tilman D, Blazer C, Hill J, Befort BL, 2011. Global food demand and the sustainable intensification of agriculture, Proceedings of the National Academy of Sciences, 108, 20260-20264

Vereecken, H., Schnepf, A., Hopmans, J.W., Javaux, M., Or, D., Roose, T., Vanderborght, J., Young, M.H., Amelung, W., Aitkenhead, M. and Allison, S.D., 2016. Modeling soil processes: Review, key challenges, and new perspectives. Vadose Zone Journal, 15.

Vanbergen, A.J. and the Insect Pollinators Initiative, 2013. Threats to an ecosystem service: pressures on pollinators. Frontiers in Ecology and the Environment, 11, 251-259.

van der Plas, F., 2019. Biodiversity and ecosystem functioning in naturally assembled communities. Biological Reviews, https://doi.org/10.1111/brv.12499

Welsch, J., Songling, C., Buckley, H.L., Lehto, N.J., Jones, E.E. and Case, B.S., 2019. How many samples? Soil variability affects confidence in the use of common agroecosystem soil indicators. Ecological Indicators, 102, 401-409. 
520 agri $\square$ environment schemes significantly improve the population size of common

521 farmland bumblebee species. Molecular Ecology, 24, 1668-1680.

522 Żmihorski, M., Kotowska, D., Berg, ̊.. and Pärt, T., 2016. Evaluating conservation tools in

523 Polish grasslands: the occurrence of birds in relation to agri-environment schemes and

$524 \quad$ Natura 2000 areas. Biological Conservation, 194, 150-157.

525 


\section{Boxes}

\section{Box 1 - Glossary of terms}

529 Agroecosystems are ecosystems that have been modified from their natural state through

530 time by farming practices, and may also contain other land uses such as settlements,

531 conservation land or other industry. Like natural ecosystems, agroecosystems are composed

532 of organisms (including humans) interacting with each other within an abiotic (chemical and

533 physical) context.

535 Non-production vegetation elements, which are not directly involved in the farm operation,

536 include trees and woody shrubs, herbaceous vegetation and wetlands. These elements can

537 vary in their size, shape, arrangement in the agricultural landscape, and in their species

538 composition.

540 These vegetation elements are the main components of 'functional biodiversity' on farms, in

541 that they support a range of flora and fauna that contribute to key ecosystem processes, such

542 as animal dispersal, pollination, and carbon and nutrient cycling, that determine overall

\section{3 ecosystem function.}

545 Human-derived benefits may arise from functioning ecosystems in the form of ecosystem

546 services, such as clean water, healthy soils, increased crop production, and overall well-

547 being. Conversely, functional biodiversity may lead to ecosystem disservices, such as the

548 facilitation of pest, disease, or weed spread and the knock-on effects for humans.

550 Multifunctionality can arise in agricultural landscapes with high functional biodiversity,

551 intact ecosystem processes, and which are generating multiple ecosystem services.

553 Sustainable and resilient agroecosystems are those which exhibit the ability as a whole to

554 withstand disturbance and/or species loss while supporting farm production into the future. 


\section{Box 2. Filling the gap: A synthetic approach for bullding understanding of non-production vegetation effects on agroecosystem processes}

The main components of resilient agroecosystems are likely to operate at, and interact across, different spatial scales. Therefore, the scale of observation and the methods used differs for different processes and ecosystem components (taxa, configuration of non-production vegetation, agroecosystem processes, and people). Appropriately matching the scales of observation and measurement of processes is critical to deepening our understanding of agroecosystem function.

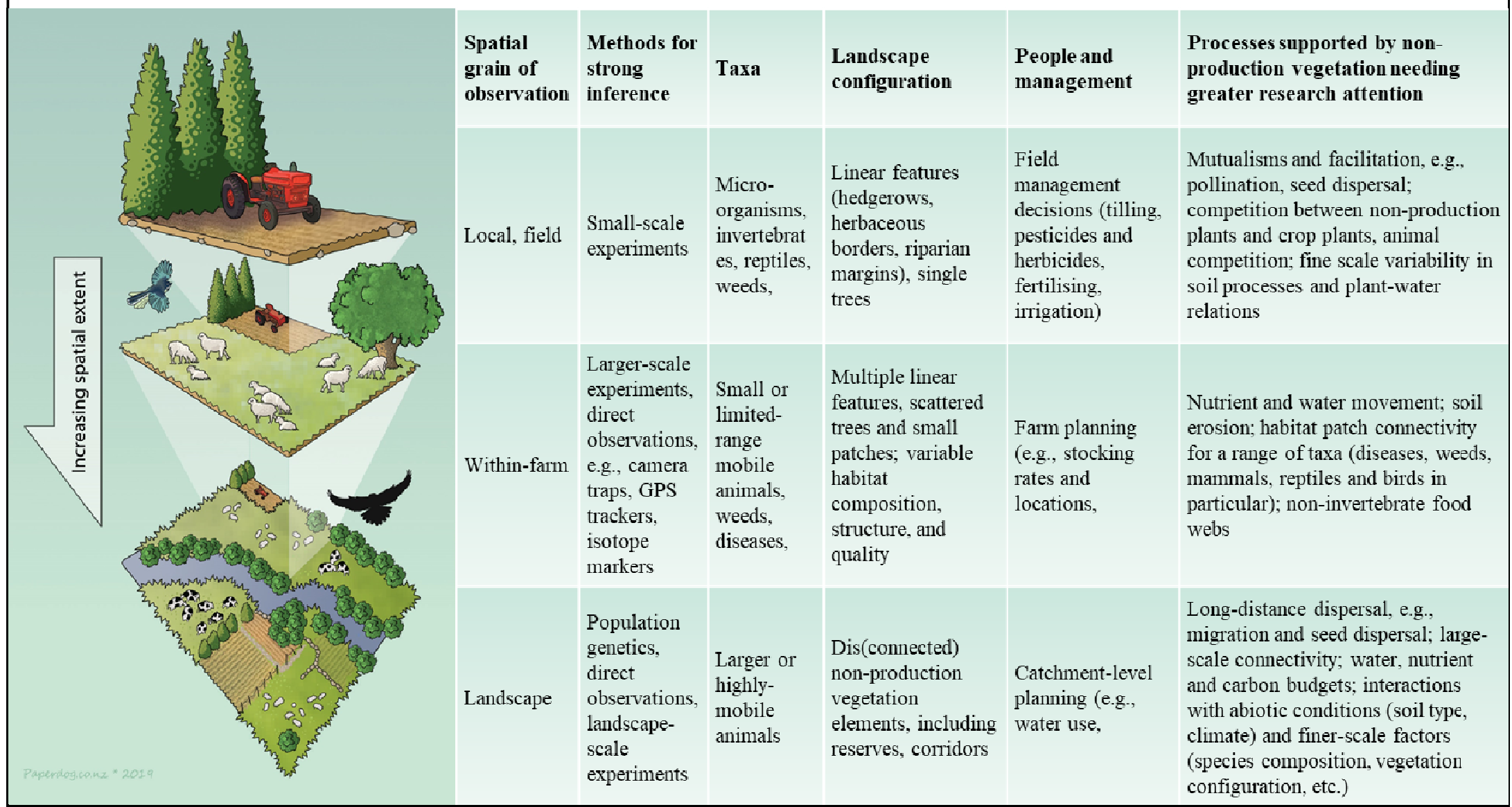



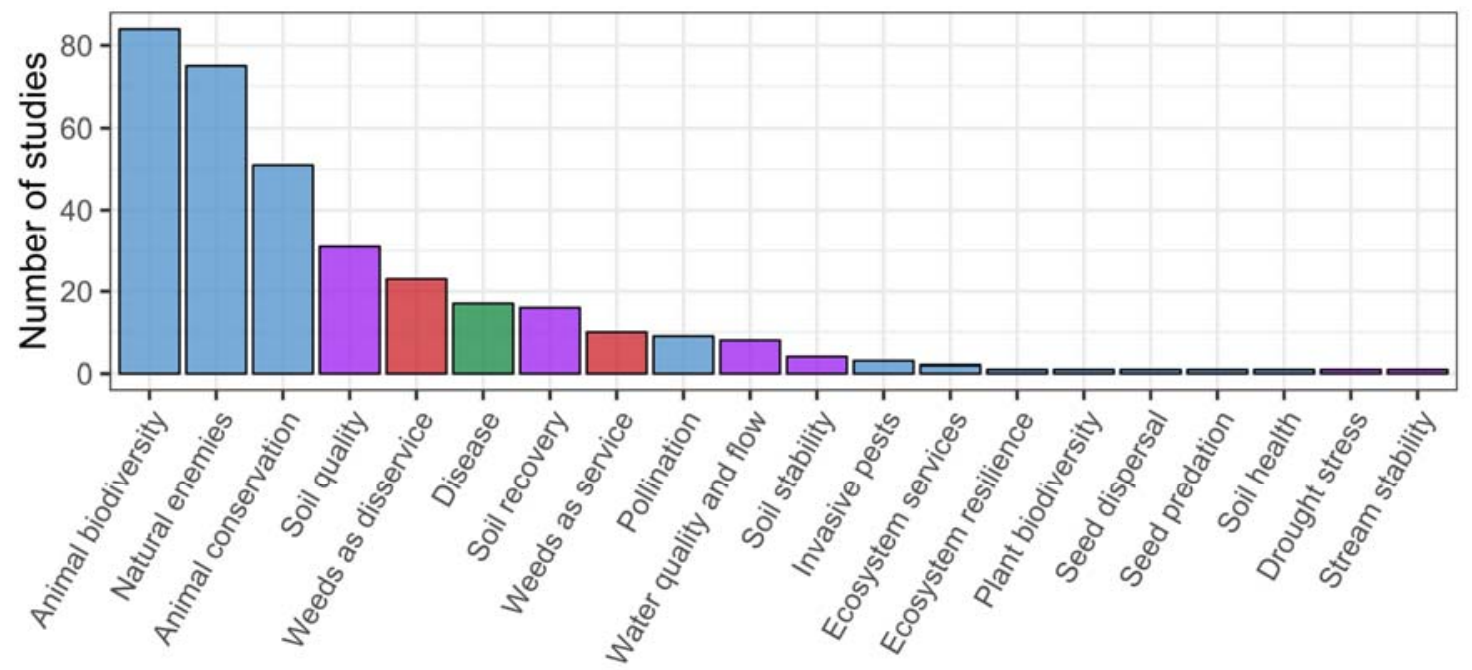

563 Figure 1: The number of total reviewed studies investigating different study aims. Over $90 \%$

564 of the total 342 reviewed studies focused on seven broad study aims with respect to the

565 effects of non-production vegetation: animal biodiversity, natural enemies (i.e., invertebrate

566 biocontrol agents), animal conservation, soil quality, weeds as an ecosystem disservice,

567 disease occurrence and/ or spread in agroecosystems (animal, plant and human), and soil

568 recovery, with the remaining $<10 \%$ of reviewed papers focusing on an additional thirteen

569 study aims. Blue bars represent fauna-related processes, purple bars represent soil and water-

570 related processes, red bars represent weed-related processes and the green bar represents

571 disease-related processes. 

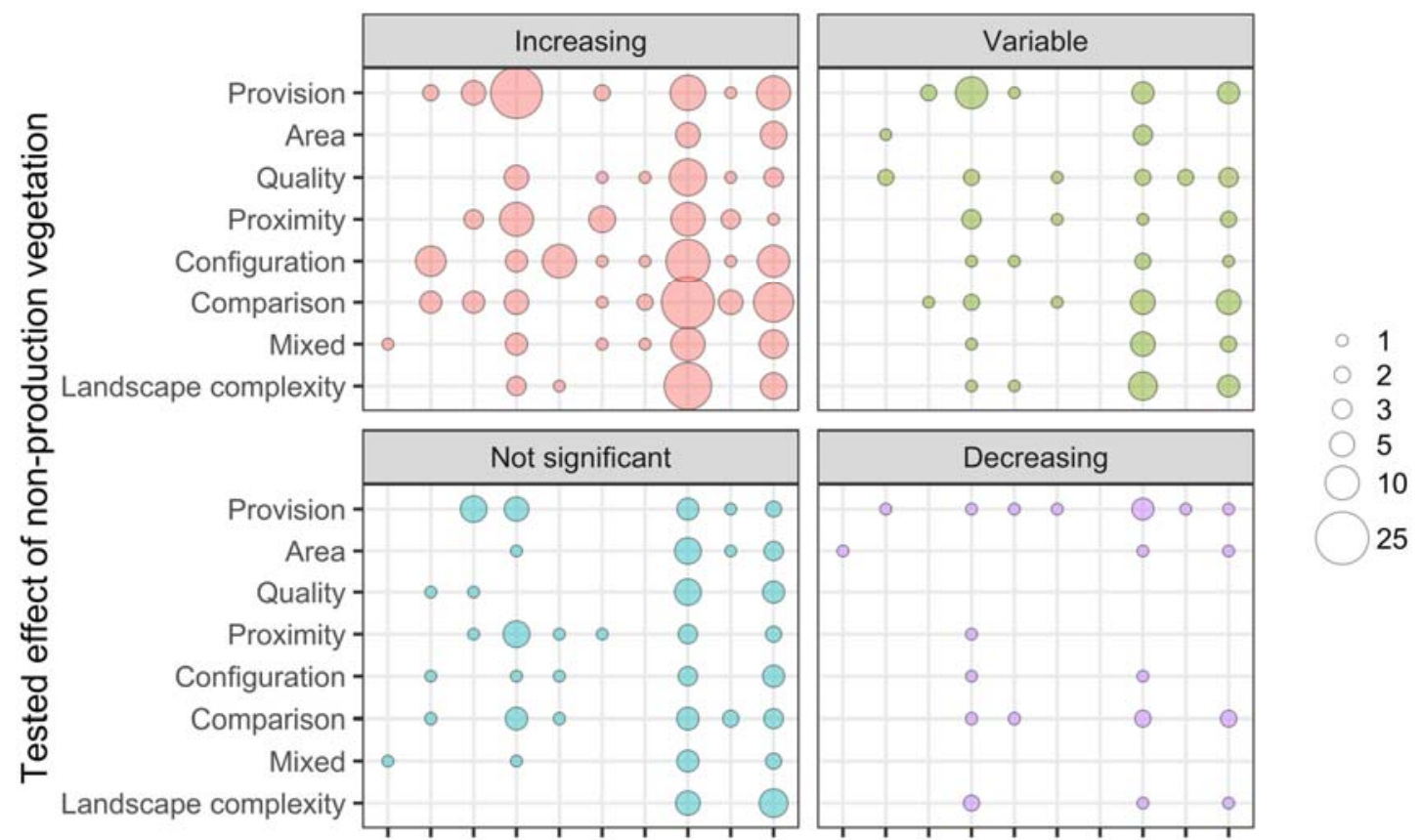

576 Figure 2: The number of studies grouped by the type of non-production vegetation and its

577 tested effect, as stated in each of the 500 research questions posed by the 342 reviewed

578 articles, including those both inferring and directly-measuring processes. The outcomes of

579 these tests were classified as 'increasing' ( $n=287$; ecosystem processes that were

580 significantly improved by the effect non-production vegetation; in the case of 'disservices',

581 the process was lessened or prevented), 'decreasing' $(n=26$; processes that were lessened or

582 prevented by the effect of non-production vegetation; in the case of 'disservices', the process

583 was increased or enhanced), 'not significant' (either a non-significant $[\mathrm{n}=74]$ or unclear $[\mathrm{n}=$

584 26] effect) and 'variable' ( $n=83$; where the outcome depended on another factor such as

585 vegetation type, taxon/taxa involved, landscape configuration or season). 


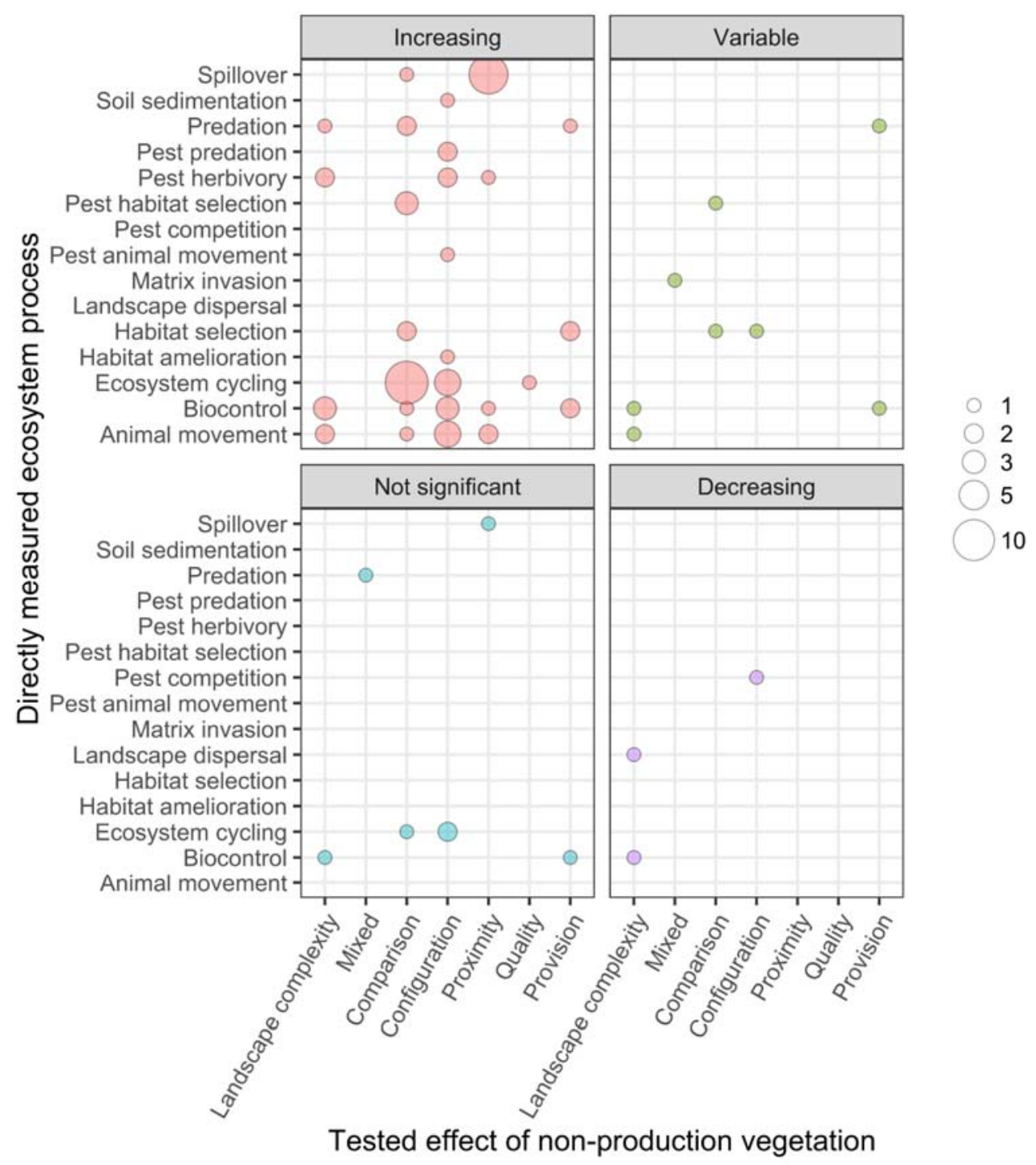

590 Figure 3: Cross -tabulation results for 84 reviewed studies where processes were directly

591 measured relating the stated, tested effects of non-production vegetation and measured

592 ecosystem processes, grouped by study outcome. As per Figure 2, outcomes of these tests

593 were classified as 'increasing', 'decreasing', 'not significant' or unclear effect and 'variable'. 


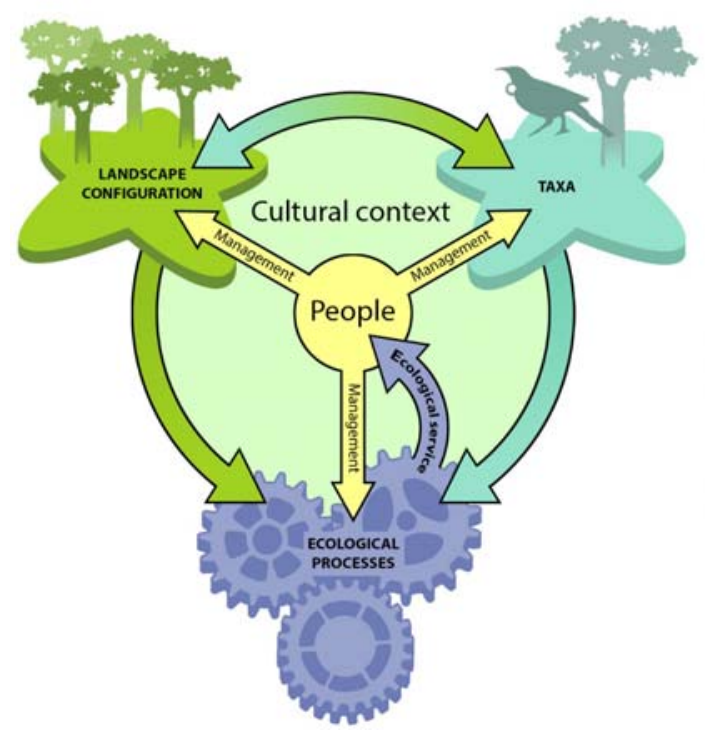

A.

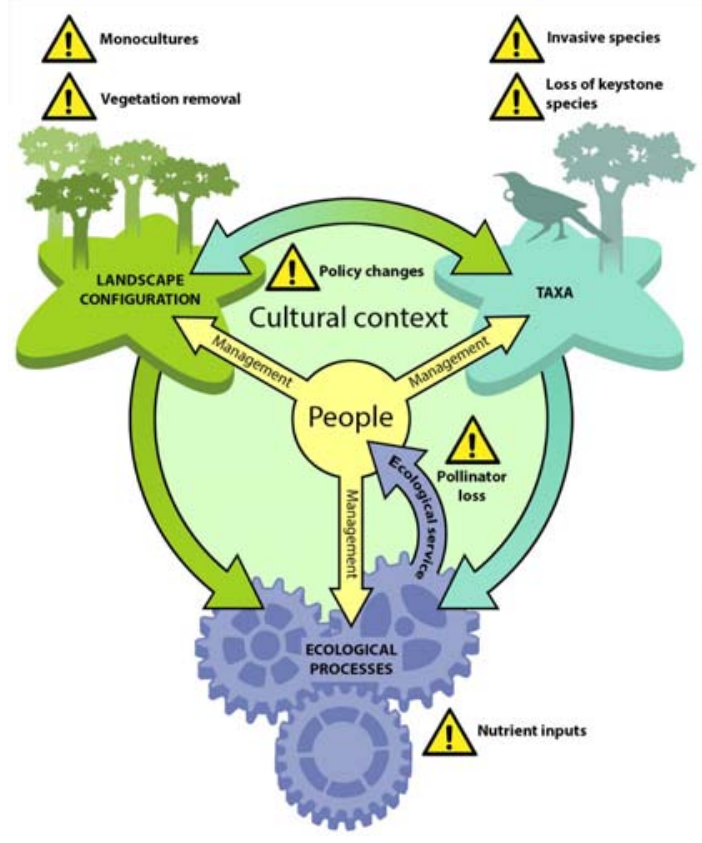

B.

Figure 4: (A) People create agroecosystems and the management of these agroecosystems depends on the cultural context, which underpins landowners' decision making. This human centre-point drives three components of multi-functionality and ecosystem resilience: (1) the taxa present in the agroecosystem, (2) the landscape configuration (including amount, arrangement and condition) of the non-production vegetation elements in the landscape, and (3) the ecological processes that are operating; taxa and landscape configuration interact to determine the ecological processes. (B) Disruption, due to management decisions, policy changes, and/or human-caused biotic and abiotic alterations, can occur for any of the components and result in the collapse in agroecosystem function and a loss of multifunctionality. To better understand how to maintain or enhance resilience, research needs to be done at multiple scales and focus on under-emphasised processes (see Box 2). 
611 Table 1: Number of research questions directly testing different agroecosystem processes and

612 the methods used to measure each process type. Ecosystem cycling refers to measurements of

613 the flux and cycling of water, carbon or nutrients. Habitat selection refers to measurements of

614 mobile animals that moved into (or, in the case of weeds, were excluded from) non-

615 production vegetation elements. Spillover refers to the movement of animals out of non-

616 production vegetation elements. Matrix invasion refers to the spread of weeds into non-

617 production vegetation elements. Direct observation refers to methods that monitored animal

618 movement such as GPS trackers and capture-recapture studies. Soil emission measurements

619 refers to studies that used experimental methods, such as incubation, to record respiration and

620 gas exchange of soils.

\begin{tabular}{llll}
\hline Study type & Process measured & Method & N \\
\hline & & & \\
Soil and water & Ecosystem cycling & Litter bag experiments & 6 \\
Soil and water & Ecosystem cycling & Soil emission measurements & 9 \\
Soil and water & Ecosystem cycling & Isotope measurements & 1 \\
Soil and water & Ecosystem cycling & Mass balance measurements & 1 \\
Soil and water & Ecosystem cycling & Multiple methods & 1 \\
Soil and water & Ecosystem cycling & Piezometer experiment & 1 \\
Soil and water & Soil sedimentation & Sediment accumulation & 1 \\
Fauna & Animal movement & Direct observation & 8 \\
Fauna & Animal movement & Population genetics & 2 \\
Fauna & Biocontrol & Food consumption amount or rate & 15 \\
Fauna & Habitat selection & Direct observation & 6 \\
Fauna & Pest animal movement & Direct observation & 1 \\
Fauna & Pest competition & Direct observation & 1 \\
Fauna & Pest habitat selection & Direct observation & 4 \\
Fauna & Pest herbivory & Food consumption amount or rate & 5 \\
Fauna & Pest predation & Direct observation & 1 \\
Fauna & Pest predation & Food consumption amount or rate & 1 \\
Fauna & Predation & Food consumption amount or rate & 4 \\
Fauna & Predation & Direct observation & 2 \\
Fauna & Spillover & Food consumption amount or rate & 9 \\
Fauna & Spillover & Direct observation & 2 \\
Weeds & Habitat provision & Individual counts & 1 \\
Weeds & Matrix invasion & Tree ring counts & 1 \\
Weeds & Matrix invasion & Individual counts & 1 \\
\hline & & &
\end{tabular}

621

622 


\section{Supplementary material}

624 Figure S1: Relative frequency of studies from all searches categorised by country or

625 continent in which the research occurred.

626

627 Table S1: Search strings used in systematic literature review.

628

629 Table S2: Descriptions of the non-production vegetation elements encountered in this review.

630

631 Table S3: Description of process categories collated from literature review.

632 
bioRxiv preprint doi: https://doi.org/10.1101/624635; this version posted May 3, 2019. The copyright holder for this preprint (which was not certified by peer review) is the author/funder. All rights reserved. No reuse allowed without permission.

633

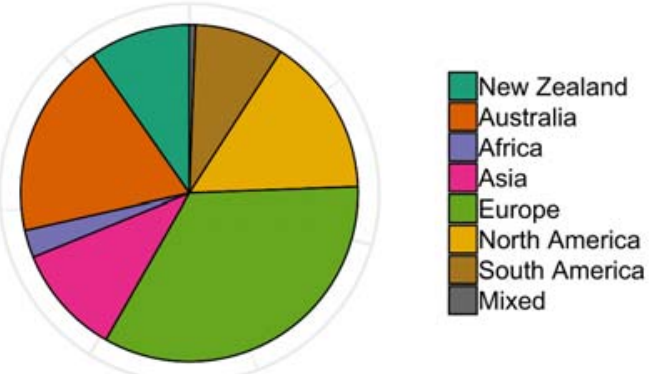

634 S1 Figure: Relative frequency of studies from all searches categorised by country or

635 continent in which the research occurred.

636

637 
639 Table S1: Search strings used in systematic literature review, for each of the five general

640 themes, both initial strings and after updating after cross-checking against article keywords.

641 Strings formatted for use in Google Scholar; other scholarly databases require different

642 formatting.

\begin{tabular}{|c|c|c|}
\hline Topic & First Search String & Updated Search String \\
\hline Fauna & $\begin{array}{l}\text { (native AND habitat) AND (fauna OR } \\
\text { animal OR invertebrate OR bird OR } \\
\text { bat) AND (biodiversity OR remnant OR } \\
\text { restoration OR richness OR corridor OR } \\
\text { barrier OR connect OR dispersal OR } \\
\text { migration) NOT (fish OR aquatic) }\end{array}$ & $\begin{array}{l}\text { (native AND habitat) AND (fauna OR } \\
\text { invertebrate OR bird OR bat) AND } \\
\text { (biodiversity OR remnant OR } \\
\text { restoration OR corridor OR barrier OR } \\
\text { connect OR dispersal OR migration OR } \\
\text { recolonization OR revegetation OR } \\
\text { occupancy) NOT (marine OR aquatic) }\end{array}$ \\
\hline Spatial & $\begin{array}{l}\text { (biodiversity AND farm) AND } \\
\text { (agroecology OR beef OR lamb OR } \\
\text { cattle OR sheep OR grazing) AND } \\
\text { ("ecosystem services" OR "ecological } \\
\text { function" OR indicator OR richness OR } \\
\text { scale OR landscape OR patch OR } \\
\text { layout) }\end{array}$ & $\begin{array}{l}\text { (biodiversity AND agriculture) AND } \\
\text { (agroecology OR beef OR lamb OR } \\
\text { cattle OR sheep OR pasture) AND } \\
\text { ("ecosystem services" OR "ecological } \\
\text { function" OR indicator OR richness OR } \\
\text { scale OR landscape OR patch OR } \\
\text { layout) }\end{array}$ \\
\hline Disease & $\begin{array}{l}\text { (habitat AND invasive) AND (pest OR } \\
\text { alien OR exotic OR disease OR weed } \\
\text { OR pathogen OR predator) AND } \\
\text { (connectivity OR dispersal OR } \\
\text { fragmentation OR corridor) NOT (fish } \\
\text { OR aquatic) }\end{array}$ & $\begin{array}{l}\text { (habitat AND invasive) AND (pest OR } \\
\text { alien OR exotic OR disease OR weed } \\
\text { OR pathogen OR zoonoses OR } \\
\text { predator) AND (connectivity OR } \\
\text { dispersal OR fragmentation OR corridor } \\
\text { OR revegetation) NOT (marine OR } \\
\text { aquatic) }\end{array}$ \\
\hline Weeds & $\begin{array}{l}((\text { agri* OR agro* OR farm*) AND } \\
\text { weed* AND (vegetation OR woody OR } \\
\text { riparian OR plant*) AND biodiversity } \\
\text { AND ecol* AND (effect OR impact) } \\
\text { NOT review NOT wetland*) }\end{array}$ & $\begin{array}{l}((\text { agri* OR agro* OR farm*) AND } \\
\text { weed* AND (vegetation OR woody OR } \\
\text { riparian OR plant*) AND biodiversity } \\
\text { AND ecol* AND (effect OR impact) } \\
\text { NOT review NOT wetland*) }\end{array}$ \\
\hline Abiotic & $\begin{array}{l}\text { (agr* OR farm*) AND (vegetation OR } \\
\text { non-crop) AND process AND function* } \\
\text { AND eco* AND (abiotic OR } \\
\text { decomposition OR sequestration OR } \\
\text { carbon OR nutrient* OR respir* OR } \\
\text { quality OR flamm* OR phyto* OR } \\
\text { soil*) AND NOT (review OR wetland) }\end{array}$ & $\begin{array}{l}\text { (agr* OR farm*) AND (vegetation OR } \\
\text { non-crop) AND process AND function* } \\
\text { AND eco* AND (abiotic OR } \\
\text { decomposition OR sequestration OR } \\
\text { carbon OR nutrient* OR respir* OR } \\
\text { quality OR flamm* OR phyto* OR } \\
\text { soil*) AND NOT (review OR wetland) }\end{array}$ \\
\hline
\end{tabular}


646 Table S2: Descriptions of the non-production vegetation elements encountered in this review.

\begin{tabular}{|c|c|}
\hline $\begin{array}{l}\text { Non-production } \\
\text { vegetation element }\end{array}$ & Description \\
\hline Mixed & A mix of different non-production vegetation element types \\
\hline Reserve & $\begin{array}{l}\text { A large area of native vegetation outside of agricultural } \\
\text { production }\end{array}$ \\
\hline Corridor & $\begin{array}{l}\text { A linear non-production vegetation element, specifically } \\
\text { described as facilitating the movement of animals, pests or } \\
\text { diseases within a landscape }\end{array}$ \\
\hline Patch & $\begin{array}{l}\text { A non-linear (round or rectangular) non-production vegetation } \\
\text { element, greater than field scale }\end{array}$ \\
\hline Riparian margins & $\begin{array}{l}\text { Usually linear non-production vegetation element alongside } \\
\text { rivers or creeks }\end{array}$ \\
\hline Shelterbelts & $\begin{array}{l}\text { Linear non-production vegetation elements planted on farms for } \\
\text { shelter and shade }\end{array}$ \\
\hline Hedgerows/borders & $\begin{array}{l}\text { Linear non-production vegetation elements occurring between } \\
\text { fields }\end{array}$ \\
\hline Scattered individuals & Multiple individual trees within a farm \\
\hline Plots & Small-scale (within field) experimental plantings \\
\hline Single trees & An individual tree \\
\hline Understorey & $\begin{array}{l}\text { Non-production vegetation planted underneath orchard or other } \\
\text { crop vegetation }\end{array}$ \\
\hline
\end{tabular}


649 Table S3. Description of process categories collated from literature review.

\begin{tabular}{|c|c|c|}
\hline Process category & Combined category & Description \\
\hline Biocontrol & Biocontrol & $\begin{array}{l}\text { Control of pests in production vegetation via } \\
\text { predation that is not parasitoids and does not } \\
\text { involve spillover from plantings or adjacent } \\
\text { non-production elements }\end{array}$ \\
\hline Biocontrol spillover & Spillover & $\begin{array}{l}\text { Pest control via predation that is not } \\
\text { parasitoids that involves predators moving } \\
\text { from non-production elements into } \\
\text { production vegetation and controlling pest } \\
\text { prey }\end{array}$ \\
\hline Parasitoid biocontrol & Biocontrol & $\begin{array}{l}\text { Control of pests in production vegetation via } \\
\text { predation by parasitoids }\end{array}$ \\
\hline $\begin{array}{l}\text { Parasitoid biocontrol } \\
\text { spillover }\end{array}$ & Spillover & $\begin{array}{l}\text { Pest control via parasitoid predation that } \\
\text { involves parasitoids moving from non- } \\
\text { production elements into production } \\
\text { vegetation and controlling pest prey }\end{array}$ \\
\hline Predation & Predation & $\begin{array}{l}\text { Predation that does not involve control of } \\
\text { pests in production vegetation (includes seed } \\
\text { predation) }\end{array}$ \\
\hline Predator spillover & Spillover & $\begin{array}{l}\text { Predation of non-pest prey by animals that } \\
\text { are not parasitoids that involves predators } \\
\text { moving from non-production elements into } \\
\text { production vegetation (predation may have } \\
\text { been inferred or measured; includes seed } \\
\text { predation) }\end{array}$ \\
\hline Pollinator spillover & Spillover & $\begin{array}{l}\text { Movement of animals that pollinate } \\
\text { production vegetation from non-production } \\
\text { elements into production vegetation } \\
\text { (predation may have been inferred or } \\
\text { measured) }\end{array}$ \\
\hline Pest spillover & Spillover & $\begin{array}{l}\text { Disservice: Movement of pest animals from } \\
\text { non-production elements into production } \\
\text { vegetation }\end{array}$ \\
\hline Landscape dispersal & Dispersal & $\begin{array}{l}\text { Dispersal at landscape scales between non- } \\
\text { production or production elements that does } \\
\text { not involve the use of corridors, nor explicitly } \\
\text { tests matrix permeability (at larger scales } \\
\text { than within a habitat or across habitat edges) }\end{array}$ \\
\hline Corridor dispersal & Dispersal & $\begin{array}{l}\text { Movement of animals through linear non- } \\
\text { production vegetation elements at a } \\
\text { landscape scale (not planted borders, } \\
\text { hedgerows or strips within or next to fields; } \\
\text { at larger scales than within a habitat or across } \\
\text { habitat edges) }\end{array}$ \\
\hline
\end{tabular}




\begin{tabular}{|c|c|c|}
\hline Matrix dispersal & Dispersal & $\begin{array}{l}\text { Dispersal at landscape scales across } \\
\text { inhospitable or impermeable landscape } \\
\text { elements (at larger scales than within a } \\
\text { habitat or across habitat edges) }\end{array}$ \\
\hline Pest dispersal & Dispersal & $\begin{array}{l}\text { Movement of pest animals at a landscape } \\
\text { scale driven by the presence of non- } \\
\text { production vegetation elements }\end{array}$ \\
\hline Seed dispersal & Dispersal & $\begin{array}{l}\text { Animal consumption or seeds or fruits } \\
\text { without seed mortality }\end{array}$ \\
\hline Habitat selection & Habitat selection & $\begin{array}{l}\text { Choice and movement of animals between } \\
\text { different landscape elements including either } \\
\text { production and/ or non-production habitat } \\
\text { types }\end{array}$ \\
\hline Habitat provision & Habitat provision & $\begin{array}{l}\text { Changes in animal population density driven } \\
\text { by the presence of non-production vegetation } \\
\text { elements }\end{array}$ \\
\hline Pest competition & Competition & $\begin{array}{l}\text { Disservice: Direct or indirect negative } \\
\text { interactions between native and pest animal } \\
\text { species driven by the presence of non- } \\
\text { production vegetation elements }\end{array}$ \\
\hline Pest habitat selection & Habitat selection & $\begin{array}{l}\text { Disservice: Choice of pest animals between } \\
\text { different landscape elements including either } \\
\text { production and/ or non-production habitat } \\
\text { types }\end{array}$ \\
\hline Pest herbivory & Herbivory & $\begin{array}{l}\text { Disservice: Damage of pest animals to } \\
\text { production vegetation }\end{array}$ \\
\hline Pest predation & Predation & $\begin{array}{l}\text { Disservice: Predation by pest animals of } \\
\text { native animals }\end{array}$ \\
\hline
\end{tabular}


bioRxiv preprint doi: https://doi.org/10.1101/624635; this version posted May 3, 2019. The copyright holder for this preprint (which was not certified by peer review) is the author/funder. All rights reserved. No reuse allowed without permission.

652 